\title{
PENGARUH HARGA, KUALITAS PRODUK, DAN CITRA MEREK TERHADAP KEPUTUSAN PEMBELIAN KECAP MANIS MEREK BANGO
}

\author{
Irvan Stanlie \\ Alumni Program Manajemen S1 \\ Sekolah Tinggi Ilmu Ekonomi Bisnis Indonesia, Jakarta \\ Meslo Pardede \\ Dosen STIE Bisnis Indonesia, Jakarta
}

\begin{abstract}
From the analysis using multiple linear regression method, the obtained results that variable of price has a significant impact on buying decision with result $t$-test (partial) obtained $t$ value $>$ t table $(3.693>1.993)$ with significant obtained about $0.000<0.05$ then Ho rejected and Ha accepted. Variable of product quality has a significant impact on buying decision with result t-test (partial) obtained t value $>$ t table $(2.787>1.993)$ with significant value obtained about $0.007<0.05$ then Ho rejected and Ha accepted. Variable of brand image has a significant impact on buying decision with result t-test (partial) obtained $t$ value $>$ t table $(2.289>1.993)$ with significant value obtained about $0.025<0.05$, then Ho rejected and Ha accepted. Variable of price, product quality, and brand image that simultaneous has a significant impact on buying decision with result F-test (simultaneous) obtained $F$ value $>F$ table $(17.126>2.730)$ with significant value obtained about $0.000<0.05$ then Ho rejected and Ha accepted. Dimensions Coefficient of determination about 0.389 or $38.9 \%$ which means independent variables consisting of price, product quality, and brand image has a contribution obtained 38.9\% toward buying decision, while the remaining (100\% $38.9 \%=61.1 \%$ ) was influenced by factors other factors that are not discussed in this study.
\end{abstract}

Keywords: Price, Product Quality, Brand Image, Buying Decision

\begin{abstract}
Abstrak: Dari hasil analisis dengan menggunakan model regresi linier berganda, diperoleh hasil perhitungan bahwa variabel harga berpengaruh signifikan terhadap keputusan pembelian dengan hasil uji $\mathrm{t}$ (parsial) didapat $\mathrm{t}$ hitung $>\mathrm{t}$ tabel $(3,693>1,993)$ dengan nilai signifikasinya didapat sebesar $0,000<0,05$, maka Ho ditolak dan Ha diterima. Variabel kualitas produk berpengaruh signifikan terhadap keputusan pembelian dengan hasil uji $\mathrm{t}$ (parsial) didapat $\mathrm{t}$ hitung $>\mathrm{t}$ tabel $(2,787$ $>1,993$ ) dengan nilai signifikasinya didapat sebesar $0,007<0,05$, maka Ho ditolak dan Ha diterima. Variabel citra merek berpengaruh signifikan terhadap keputusan pembelian dengan hasil uji $t$ (parsial) didapat thitung $>\mathrm{t}$ tabel $(2,289>1,993)$ dengan nilai signifikasinya didapat sebesar $0,025<$ 0,05, maka Ho ditolak dan Ha diterima. Variabel harga, kualitas produk, dan citra merek secara simultan berpengaruh signifikan terhadap keputusan pembelian dengan hasil uji $\mathrm{F}$ (simultan) didapat $\mathrm{F}$ hitung $>\mathrm{F}$ tabel $(17,126>2,730)$ dengan nilai signifikasinya didapat sebesar $0,000<0,05$, maka Ho ditolak dan Ha diterima. Besarnya koefisien determinasi sebesar 0,389 atau 38,9\% yang berarti variabel-variabel bebas yang terdiri dari harga, kualitas produk, dan citra merek dapat memberikan kontribusi sebesar $38,9 \%$ terhadap keputusan pembelian, sedangkan sisanya $(100 \%$ $38,9 \%=61,1 \%$ ) dipengaruhi oleh faktor-faktor lain yang tidak dibahas di dalam penelitian ini.
\end{abstract}

Kata kunci: Harga, Kualitas Produk, Citra Merek, Keputusan Pembelian 


\section{Pendahuluan}

Era globalisasi menjanjikan suatu peluang dan tantangan bisnis baru bagi perusahaan yang beroperasi di Indonesia. Di satu sisi, era globalisasi memperluas pasar produk dari perusahaan Indonesia, sementara di sisi lain, keadaan tersebut memunculkan persaingan yang semakin ketat baik antar perusahaan domestik maupun perusahaan asing. Seperti halnya yang terjadi pada usaha ritel nasional, dimana perkembangan usaha retail di Indonesia pada saat ini cukup pesat (Fuad, 2012). Pasar ritel barang konsumen di Indonesia berkembang baik sekali. Pertumbuhan ekonomi di era globalisasi ini menuntut setiap perusahaan baik yang bergerak di bidang industri barang maupun jasa untuk mampu bersaing dengan perusahaan lainnya dan perusahaan yang bergerak di sektor industri harus mampu meningkatkan kompetensinya untuk dapat merebut pangsa pasar. Industri kecap merupakan salah satu industri yang berpeluang cukup besar dengan persaingan yang semakin meningkat. Kecap Bango merupakan salah satu industri kecap yang mampu bersaing dengan pasar kecap yang ada di Indonesia.

Banyak faktor yang menyebabkan konsumen dalam melakukan keputusan pembelian produk kecap manis merek Bango, seperti harga, kualitas produk, dan citra merek produk tersebut. Apabila dilihat dari faktor harga dan kualitas produk, Bango merupakan satu-satunya kecap yang menggunakan bahan alami dari kedelai hitam sehingga produknya lebih kental, lebih manis, dan lebih meresap ke dalam masakan. Karena kualitas bahan unggulan seperti itu, Bango berfokus pada segmen premium (kelas A dan B) dengan harga di atas rata-rata harga kecap pada umumnya. Dilihat dari faktor merek, kecap Bango adalah salah satu produk yang sangat dikenal masyarakat dimana brand awareness-nya sangat tinggi. Keputusan pembelian kebutuhan dapur, seperti kecap biasanya ditentukan oleh ibu rumah tangga. Maka produsen kecap yang salah satu segmentasi pasarnya adalah ibu-ibu yang perlu diperhatikan dalam pangsa pasar ini. Apabila dilihat dari segmentasi pasar mengenai citra merek dan harga bahwa kinerja sebuah citra merek merupakan faktor terpenting untuk tetap setia pada merek tersebut. Perusahaan harus dapat meyakinkan bahwa produk yang dibeli oleh konsumen dapat berfungsi dan bekerja dengan baik sehingga dapat memberikan manfaat sesuai dengan yang dijanjikan. Apabila dilihat dari segi harga yang ditawarkan harus konsisten, mudah dipahami, dan sesuai dengan nilai produk yang diinginkan konsumen. Berdasarkan uraian di atas penulis tertarik untuk mengangkat judul "Pengaruh Harga, Kualitas Produk, Dan Citra Merek Terhadap Keputusan Pembelian Kecap Manis Merek Bango”.

\section{Landasan Teori}

\subsection{Manajemen}

Sebuah perusahaan atau organisasi tentu mempunyai tujuan dan tujuan tersebut berbeda-beda tergantung dari jenis organisasinya, misalnya: organisasi bisnis tentu akan mempunyai tujuan untuk mendapatkan keuntungan dalam menjalankan usahanya. Menurut Terry dan Rue (2016:1) "Manajemen adalah suatu proses atau kerangka kerja yang melibatkan bimbingan atau pengarahan suatu kelompok orang-orang ke arah tujuan-tujuan organisasional atau maksud-maksud yang nyata".

\subsubsection{Manajemen pemasaran}

Menurut Stanton dalam Sunyoto (2014:18) "Pemasaran adalah suatu sistem total dari kegiatan bisnis yang dirancang untuk merencanakan, menentukan harga, promosi, dan mendistribusikan barangbarang yang dapat memuaskan keinginan dan mencapai pasar sasaran serta tujuan perusahaan". Sedangkan menurut Shultz dalam Alma (2016:130) "Manajemen pemasaran adalah merencanakan, pengarahan dan pengawasan seluruh kegiatan pemasaran perusahaan ataupun bagian dari perusahaan". 


\subsubsection{Harga}

Menurut Etzel dalam Sunyoto (2014:130) "Harga adalah nilai yang disebutkan dalam mata uang sebagai alat tukar". Di dalam ilmu ekonomi, pengertian harga mempunyai hubungan dengan pengertian nilai dan kegunaan. Nilai adalah ukuran jumlah yang diberikan oleh suatu produk apabila produk itu ditukarkan dengan produk lain. Sedangkan kegunaan adalah atribut dari sebuah item yang memberikan tingkat kepuasan tertentu pada konsumen. Menurut Gitosudarmo dalam Sunyoto (2014:131) "Harga itu sebenarnya merupakan nilai yang dinyatakan dalam satu mata uang atau alat tukar, terhadap suatu produk tertentu". Menurut Tjiptono (2017:370) harga memainkan peranan penting bagi perekonomian secara makro, konsumen dan perusahaan.

1. Bagi perekonomian.

2. Bagi konsumen.

3. Bagi perusahaan.

\subsubsection{Kualitas Produk}

Kualitas produk merupakan hal yang perlu mendapat perhatian utama dari perusahaan atau produsen, mengingat kualitas suatu produk berkaitan erat dengan masalah kepuasan konsumen, yang merupakan tujuan dari kegiatan pemasaran yang dilakukan perusahaan. Assauri (2017:212) menyatakan bahwa "Kualitas produk menunjukkan ukuran tahan lamanya produk itu, dapat dipercayainya produk tersebut, ketepatan produk, mudah mengoperasikan dan memeliharanya serta atribut lain yang dinilai". Dari segi pandangan pemasaran, kualitas diukur dalam ukuran persepsi pembeli tentang mutu atau kualitas produk tersebut. Kebanyakan produk disediakan atau diadakan mulanya berawal pada satu di antara empat tingkat kualitas, yaitu kualitas rendah, kualitas rata-rata (sedang), kualitas baik (tinggi), dan kualitas sangat baik. Dari produk yang biasa dibeli oleh konsumen, kita dapat melakukan penggolongan atau klasifikasi mengenai produk. Menurut Sunyoto (2014:73), produk menurut daya tahannya diklasifikasikan menjadi tiga kelompok, yaitu:

1. Barang yang tahan lama

2. Barang yang tidak tahan lama

3. Jasa

\subsubsection{Citra Merek}

Menurut Pradipta (2012:25) "Citra merek (brand image) merupakan presentasi dari keseluruhan persepsi terhadap merek itu". Citra terhadap merek berhubungan dengan sikap yang berupa keyakinan dan preferensi terhadap suatu merek. Menurut Rangkuti dalam Sangadji dan Sopiah (2013:327) “Citra merek adalah sekumpulan asosiasi merek yang terbentuk di benak konsumen".

\subsubsection{Keputusan Pembelian}

Proses pengambilan keputusan pembelian sangat dipengaruhi oleh perilaku konsumen. Proses tersebut sebenarnya merupakan proses pemecahan masalah dalam rangka memenuhi keinginan atau kebutuhan konsumen. Menurut Peter dan Olson dalam Sangadji dan Sopiah (2013:332) "Keputusan pembelian konsumen adalah proses pemecahan masalah yang diarahkan pada sasaran". Lebih lengkap lagi, Peter dan Olson dalam Sangadji dan Sopiah (2013:332) "Keputusan pembelian konsumen adalah proses pengintegrasian yang mengombinasikan pengetahuan untuk mengevaluasi dua perilaku alternatif atau lebih dan memilih salah satu di antaranya". Pengambilan keputusan konsumen meliputi semua proses yang dilalui konsumen untuk mengenali masalah, mencari solusi, mengevaluasi alternatif dan memilih di antara pilihan-pilihan. Menurut Engel et al dalam Sangadji dan Sopiah (2013:332) "Perilaku pembelian adalah proses keputusan dan tindakan orang-orang yang terlibat dalam pembelian dan penggunaan produk". 


\subsection{Kerangka Pikir}

Menurut Sekaran dalam Sugiyono (2016:60) "Kerangka pikir merupakan model konseptual tentang bagaimana teori berhubungan dengan berbagai faktor yang telah diindentifikasi sebagai masalah yang penting".

Gambar 2.1

Kerangka Pikir

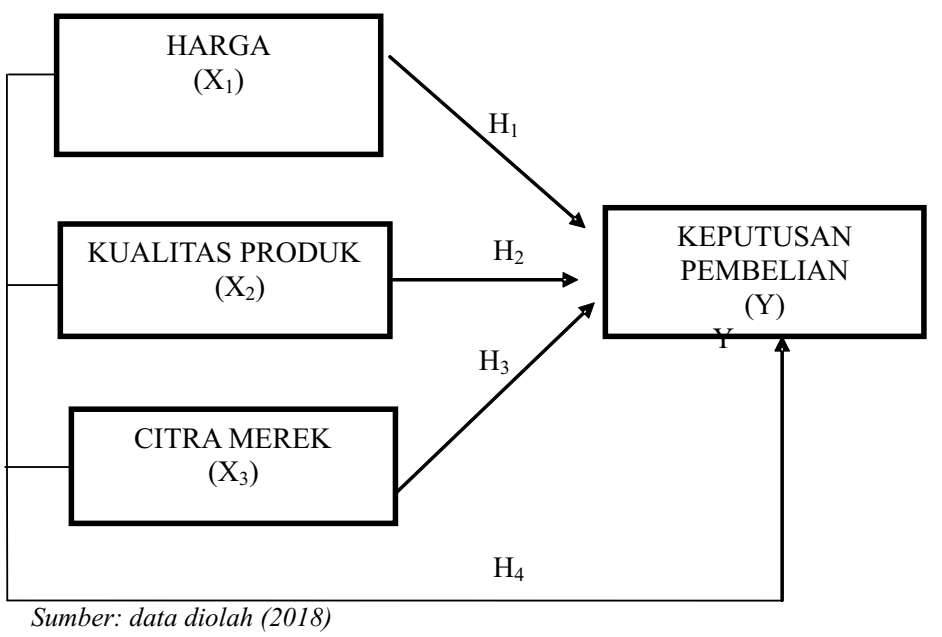

\subsection{Hipotesis}

Menurut Sujarweni (2015:68) "Hipotesis merupakan jawaban sementara terhadap tujuan penelitian yang diturunkan dari kerangka pemikiran yang telah dibuat. Hipotesis merupakan pernyataan tentatif tentang hubungan antara beberapa dua variabel atau lebih". Sesuai dengan masalah yang diteliti, maka dapat dikemukakan hipotesis sebagai berikut:

\section{Hipotesis 1}

$\mathrm{Ho}_{1}$ : diduga tidak ada pengaruh signifikan secara parsial antara harga terhadap keputusan pembelian kecap manis merek Bango.

$\mathrm{Ha}_{1}$ : diduga ada pengaruh signifikan secara parsial antara harga terhadap keputusan pembelian kecap manis merek Bango.

\section{Hipotesis 2}

$\mathrm{Ho}_{2}$ : diduga tidak ada pengaruh signifikan secara parsial antara kualitas produk terhadap keputusan pembelian kecap manis merek Bango.

$\mathrm{Ha}_{2}$ : diduga ada pengaruh signifikan secara parsial antara kualitas produk terhadap keputusan

\section{Hipotesis 3} pembelian kecap manis merek Bango.

$\mathrm{Ho}_{3}$ : diduga tidak ada pengaruh signifikan secara parsial antara citra merek terhadap keputusan pembelian kecap manis merek Bango.

$\mathrm{Ha}_{3}$ : diduga ada pengaruh signifikan secara parsial antara citra merek terhadap keputusan

Hipotesis 4 pembelian merek Bango.

$\mathrm{Ho}_{4}$ : diduga tidak ada pengaruh signifikan antara harga, kualitas produk, dan citra merek secara simultan terhadap keputusan pembelian kecap manis merek Bango.

$\mathrm{Ha}_{4}$ : diduga ada pengaruh signifikan antara harga, kualitas produk, dan citra merek secara simultan terhadap keputusan pembelian kecap manis merek Bango. 


\section{Metodologi Penelitian}

\subsection{Metode Penelitian}

Menurut Sujarweni (2015:49) "Penelitian asosiatif yaitu penelitian yang bertujuan untuk mengetahui hubungan antara dua variabel atau lebih. Dengan penelitian ini maka akan dapat dibangun suatu teori yang dapat menjelaskan, meramalkan, dan mengontrol suatu gejala". Variabelvariabel dalam penelitian ini meliputi tiga variabel bebas $(X)$, yaitu harga $\left(X_{1}\right)$, kualitas produk $\left(X_{2}\right)$, dan citra merek $\left(\mathrm{X}_{3}\right)$ sedangkan variabel terikat yaitu keputusan pembelian $(\mathrm{Y})$.

\subsection{Populasi dan Sampel}

Menurut Sugiyono (2016:80) "Populasi adalah wilayah generalisasi yang terdiri atas: obyek atau subyek yang mempunyai kualitas dan karakteristik tertentu yang ditetapkan oleh peneliti untuk dipelajari dan kemudian ditarik kesimpulan". Dalam penelitian ini populasinya berdomisili di wilayah RW 015 Perumahan Taman Palem Lestari, Kelurahan Cengkareng Barat, Kecamatan Cengkareng, Jakarta Barat. Teknik sampel yang digunakan dalam penelitian menggunakan non probabilita sampling dengan Sampling insidental adalah teknik penentuan sampel berdasarkan kebetulan yaitu siapa saja yang secara kebetulan/insidental bertemu dengan peneliti dapat digunakan sebagai sampel, bila dipandang orang yang kebetulan ditemui itu cocok sebagai sumber data karena keterbatasan yang diambil sebanyak 87 responden.

\subsection{Teknik Pengumpulan Data}

Menurut Sujarweni (2015:93) "Teknik pengumpulan data adalah cara yang dilakukan peneliti untuk mengungkap atau menjaring informasi dari responden sesuai lingkup penelitian". Teknik pengumpulan data yang diperlukan dalam penelitian ini dengan penyebaran kuesioner. Menurut Sugiyono (2016:142) "Kuesioner merupakan teknik pengumpulan data yang dilakukan dengan cara memberi seperangkat pertanyaan atau pernyataan tertulis kepada responden untuk dijawabnya".

\subsection{Teknik Analisis Data}

Penelitian ini melihat hubungan yang terjadi independent variable dengan dependent variable melalui korelasi. Derajat atau tingkat hubungan antara dua variabel diukur dengan menggunakan indeks korelasi, yang disebut koefisien korelasi. Dalam penelitian ini digunakan teknik korelasi sederhana dan multiple-regression analysis. Koefisien-koefisien regresi distandarisasikan untuk mengurai hubungan antara dua variabel bebas dan satu variabel terikat. Dalam pengamatan dan penganalisaan serta pengukuran normalitas, setiap faktor akan dilihat hubungan melalui korelasi sederhana. Hubungan variabel bebas dan terikat secara keseluruhan akan ditinjau lebih jauh untuk mengetahui tingkatan korelasi yang multiple. Metode analisis data yang digunakan dalam penelitian ini adalah uji Deskriptif, Uji Kualitas data (Uji validitas dan Uji reliabilitas), Analisis Regresi Linear berganda yang terdiri dari Uji Asumsi Klasik (Uji Normalitas, Uji Multikolonieritas, dan Uji Heteroskedastisitas), Uji Hipotesis (Uji Signifikansi t dan Uji F), dan Uji Koefisien Determinasi.

\section{Analisis dan Pembahasan}

\subsection{Analisis}

Metode pengolahan data yang digunakan pada penelitain ini adalah metode analisis deskriptif dan metode analisis inferensial. Metode analisis deskriptif adalah statistik yang digunakan untuk menganalisa data dengan cara mendeskripsikan atau menggambarkan data yang telah terkumpul sebagaimana adanya tanpa bermaksud membuat kesimpulan yang berlaku untuk digeneralisasikan. Termasuk dalam statistik deskriptif antara lain adalahpenyiapan data dalam bentuk tabel, grafik, perhitungan median, mean, standart deviasi, perhitungan prosentase, dan lain-lain (Sugiyono, 2009: 207). Adapun untuk kepentingan penelitian ini menggunakan program SPSS for window. 
Berdasarkan data variabel terikatnya $(\mathrm{Y})$ adalah keputusan pembelian dan variabel bebasnya adalah variabel harga $\left(\mathrm{X}_{1}\right)$, kualitas produk $\left(\mathrm{X}_{2}\right)$, dan citra merek $\left(\mathrm{X}_{3}\right)$.

\subsubsection{Uji Validitas dan Reliabilitas}

Dalam pengujian validitas keseluruhan data dinyatakan valid nilai $r$ hitung lebih kecil dati $r$ tabel maka dapat dinyatakan valid. Selanjutnya kuesioner tersebut akan digunakan dalam penelitian. Uji reliabilitas dapat dilakukan secara bersama-sama terhadap seluruh butir pertanyaan untuk lebih dari satu variabel, namun sebaiknya uji reliabilitas dilakukan pada masing-masing variabel pada lembar kerja yang berbeda sehingga dapat diketahui konstruk variabel mana yang tidak reliabel. Realibilitas suatu konstruk variabel dikatakan baik jika memiliki nilai Cronbach's Alpha > dari 0, 60 .

Tabel 4.1

Reliabilitas

\begin{tabular}{|l|c|c|c|}
\hline \multicolumn{1}{|c|}{ Variabel } & $\begin{array}{c}\text { Jumlah } \\
\text { Pernyataan }\end{array}$ & $\begin{array}{c}\text { Cronbach } \\
\text { Alpha }\end{array}$ & Keterangan \\
\hline Harga $\left(\mathrm{X}_{1}\right)$ & 10 & 0,898 & Reliabel \\
\hline Kualitas Produk $\left(\mathrm{X}_{2}\right)$ & 10 & 0,798 & Reliabel \\
\hline Citra Merek $\left(\mathrm{X}_{3}\right)$ & 10 & 0,652 & Reliabel \\
\hline Keputusan Pembelian (Y) & 10 & 0,759 & Reliabel \\
\hline Sumber: Diolah Penulis (2018) & & &
\end{tabular}

Dari tabel 4.1 diatas keseluruhan variabel dinyatakan reliabel karena nilai CR (Cronbach Alpha) lebih besar dari dari 0,60 .

\subsection{Pembahasan}

\subsubsection{Uji Asumsi Klasik}

Dalam melakukan analisa, penulis menggunakan perangkat lunak SPSS. Hasil dari analisa akan dibahas pada bagian berikut:

\section{Uji Normalitas}

Uji asumsi normalitas data yang digunakan dalam penelitian ini adalah menggunakan pendekatan grafis. Pengujian normalitas digunakan untuk melihat pola distribusi kekeliruan. Pengujian ini dapat dilakukan dengan jalan melihat grafik histogram kekeliruan yang berbentuk lonceng (distribusi normal) dan Normal P-P-plot.

Dari gambar 4.1 di atas terlihat bahwa titik-titik atau data searah dan mengikuti garis diagonal. Hal ini dapat disimpulkan bahwa data terdistribusi normal, sehingga dapat melanjutkan ke uji asumsi klasik. 


\section{Gambar 4.1.}

Hasil Uji Normalitas dengan P-P Plot

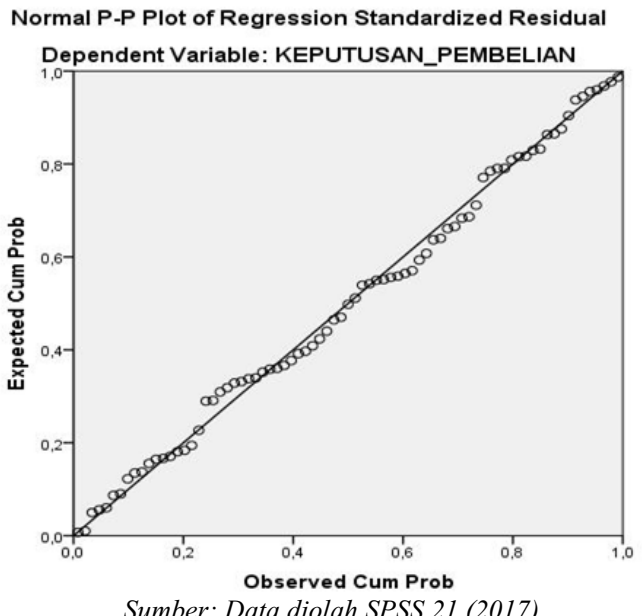

\section{Uji Multikolinearitas}

Tabel 4.2

Hasil Uji Asumsi Klasik Multikolinearitas

\begin{tabular}{|l|c|c|c|}
\hline \multirow{2}{*}{ Variabel } & \multicolumn{2}{|c|}{ Collinearity Statistics } & \multirow{2}{*}{ Keputusan } \\
\cline { 2 - 3 } & Tolerance & VIF & \\
\hline Harga & 0,941 & 1,062 & Tidak Terjadi Multikolinearitas \\
\hline Kualitas Produk & 0,688 & 1,454 & Tidak Terjadi Multikolinearitas \\
\hline Citra Merek & 0,654 & 1,528 & Tidak Terjadi Multikolinearitas \\
\hline
\end{tabular}

Dari tabel 4.2, dapat diketahui bahwa semua variabel bebas di atas mempunyai nilai tolerance lebih besar dari 0,1 dan nilai VIF lebih kecil dari 10, sehingga dapat disimpulkan bahwa tidak terjadi multikolinearitas untuk semua variabel bebas yaitu harga, kualitas produk, dan citra merek.

\section{Uji Heteroskedastisitas}

Berdasarkan gambar 4.2, terdapat titik-titik yang menyebar secara acak serta tersebar baik di atas maupun di bawah angka 0 pada sumbu Y. Hal ini dapat disimpulkan bahwa tidak terjadi Heteroskedastisitas pada model regresi, sehingga model regresi layak dipakai untuk memprediksi keputusan pembelian berdasarkan variabel bebas yaitu harga $\left(\mathrm{X}_{1}\right)$, kualitas produk $\left(\mathrm{X}_{2}\right)$, dan citra $\operatorname{merek}\left(\mathrm{X}_{3}\right)$.

\section{Gambar 4.2}

Hasil Uji Asumsi Klasik Heteroskedastisitas

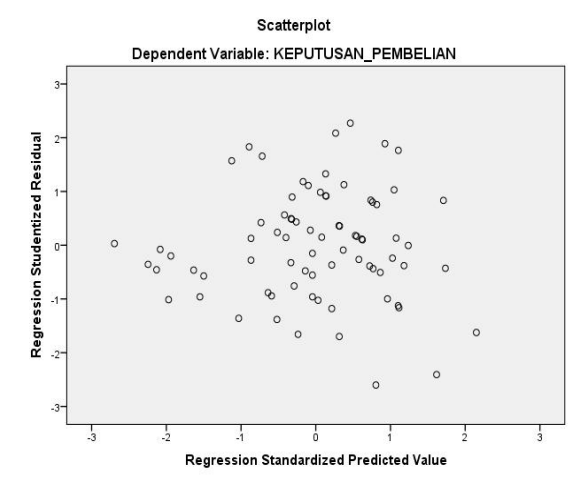


4.2.2. Analisis Regresi Berganda

Persamaan regresi linier berganda didapat sebagai berikut:

Tabel 4.3

Hasil Uji Koefisien Regresi

\begin{tabular}{|l|c|}
\hline \multicolumn{1}{|c|}{ Variabel } & Koefisien Regresi \\
\hline Constant & 10,894 \\
\hline Harga & 0,197 \\
\hline Kualitas Produk & 0,238 \\
\hline Citra Merek & 0,293 \\
\hline
\end{tabular}

Sumber: data diolah SPSS 21.0 (2018)

$Y=10,894+0,197 X_{1}+0,238 X_{2}+0,293 X_{3}$

Arti dari angka-angka tersebut adalah sebagai berikut:

1. Nilai Konstan sebesar 10,894 artinya jika harga, kualitas produk, dan citra merek konstan (tetap), maka keputusan pembelian sebesar 10,894.

2. Koefisien regresi harga sebesar 0,197 menjelaskan bahwa pengaruh harga terhadap keputusan pembelian adalah positif. Berdasarkan nilai koefisien regresi tersebut dapat disimpulkan jika variabel harga mengalami kenaikan sebesar satu satuan maka keputusan pembelian akan mengalami peningkatan sebesar 0,197 satuan dengan asumsi variabel bebas lainnya yaitu kualitas produk dan citra merek dianggap tetap atau ceteris paribus.

3. Koefisien regresi kualitas produk sebesar 0,238 menjelaskan bahwa pengaruh kualitas produk terhadap keputusan pembelian adalah positif. Berdasarkan nilai koefisien regresi tersebut dapat disimpulkan jika variabel kualitas produk mengalami kenaikan sebesar satu satuan maka keputusan pembelian akan mengalami peningkatan sebesar 0,238 satuan dengan asumsi variabel bebas lainnya yaitu harga dan citra merek dianggap tetap atau ceteris paribus.

4. Koefisien regresi citra merek sebesar 0,293 menjelaskan bahwa pengaruh citra merek terhadap keputusan pembelian adalah positif. Berdasarkan nilai koefisien korelasi regresi tersebut dapat disimpulkan jika variabel citra merek mengalami kenaikan sebesar satu satuan maka keputusan pembelian akan mengalami peningkatan sebesar 0,293 satuan dengan asumsi variabel bebas lainnya yaitu harga dan kualitas produk dianggap tetap atau ceteris paribus.

\subsubsection{Koefisien Korelasi (R) dan Koefisien Determinasi $\left(R^{2}\right)$}

Pengujian koefisien korelasi (R) bertujuan untuk mengetahui hubungan yang erat antara variabel bebas yang terdiri dari variabel harga, kualitas produk, dan citra merek terhadap variabel terikat yang terdiri dari keputusan pembelian. Sedangkan uji koefisien determinasi dilakukan untuk mengukur seberapa jauh kemampuan model dalam menerangkan variasi dari variabel terikat. Besarnya nilai $\mathrm{R}^{2}$ adalah antara 0 sampai 1 , kurang menjelaskan variasi dari variabel terikat. Nilai $\mathrm{R}^{2}$ mendekati 1 berarti variabel-variabel bebas memberikan hampir semua informasi yang dibutuhkan untuk memprediksi variasi variabel terikat. Berikut ini hasil pengujian koefisien korelasi dan koefisien determinasi:

Pada tabel 4.4 di atas besarnya koefisien korelasi (R) sebesar 0,643 atau 64,3\% yang berarti bahwa adanya korelasi atau hubungan yang kuat karena berada pada interval $0,600-0,799$ antara variabel bebas yang terdiri dari harga, kualitas produk, dan citra merek secara bersama-sama terhadap keputusan pembelian. Besarnya koefisien determinasi (adjusted $\mathrm{R}^{2}$ ) sebesar 0,389 atau 38,9\% yang 
Tabel 4.4

Hasil Koefisien Korelasi $(\mathbf{R})$ dan Koefesien Determinasi $\left(\mathbf{R}^{2}\right)$

\begin{tabular}{|l|r|r|r|c|}
\hline Model & $\mathrm{R}$ & $\mathrm{R}$ Square & $\begin{array}{c}\text { Adjusted R } \\
\text { Square }\end{array}$ & $\begin{array}{c}\text { Std. Error of the } \\
\text { Estimate }\end{array}$ \\
\hline 1 &, $643^{\mathrm{a}}$ &, 413 &, 389 & 2,49968 \\
\hline
\end{tabular}

a. Predictors: (Constant), CITRA_MEREK, HARGA,

KUALITAS_PRODUK

Sumber: data diolah SPSS 21.0 (2018)

berarti variabel-variabel bebas terdiri dari harga, kualitas produk, dan citra merek dapat memberikan kontribusi sebesar 38,9\% terhadap keputusan pembelian sedangkan sisanya $(100 \%-38,9 \%=$ $61,1 \%$ ) dipengaruhi oleh faktor-faktor lain yang tidak dibahas di dalam penelitian ini.

\subsubsection{Ujit (parsial)}

uji t. Uji t dilakukan dengan tingkat signifikasinya $(\alpha)=0,05(5 \%)$, derajat kebebasan/degree of freedom $(d f)=\mathrm{n}-\mathrm{k}-1$, dimana $\mathrm{n}$ adalah jumlah sampel, $\mathrm{k}$ adalah jumlah variabel bebas. Jika $\mathrm{n}=77$ dan $\mathrm{k}=3$ maka degree offreedom $(d f)=77-3-1=73$ dan $\alpha / 2: 0,05 / 2=0,025$, maka $\mathrm{t}_{\text {tabel }}=1,993$.

Tabel 4.5

Hasil Uji t (Parsial)

\begin{tabular}{|l|c|c|c|c|}
\hline \multicolumn{1}{|c|}{ Variabel } & $\mathbf{t}_{\text {tabel }}$ & $\mathbf{t}_{\text {hitung }}$ & Sig & Keputusan \\
\hline Constant & 1,993 & 2,723 & 0,008 & - \\
\hline Harga & 1,993 & 3,693 & 0,000 & Ho Ditolak \\
\hline Kualitas Produk & 1,993 & 2,787 & 0,007 & Ho Ditolak \\
\hline Citra Merek & 1,993 & 2,289 & 0,025 & Ho Ditolak \\
\hline
\end{tabular}

Berdasarkan tabel 4.5, dapat disimpulkan bahwa variabel harga, kualitas produk, dan citra merek berpengaruh signifikan secara parsial terhadap keputusan pembelian karena masing-masing variabel memiliki nilai $t_{\text {hitung }}$ lebih besar daripada $t_{\text {tabel }}$ dan nilai signifikan di bawah tingkat kesalahan (alpha) sebesar 0,05.

\subsubsection{Uji F (Simultan)}

Uji F digunakan untuk menguji apakah secara bersama-sama seluruh variabel bebas (harga, kualitas produk, dan citra merek) mempunyai pengaruh yang signifikan terhadap variabel terikat. Dasar pengambilan keputusan uji $\mathrm{F}$ dilakukan dengan tingkat signifikasi $(\alpha)=0,05$, derajat kebebasan $1 /$ degree of freedom $1(d f)=\mathrm{k}-1$, dimana $\mathrm{k}$ adalah jumlah semua variabel (variabel bebas dan variabel terikat). Dan derajat kebebasan 2/degree of freedom $2(d f)=\mathrm{n}-\mathrm{k}$, dimana $\mathrm{n}$ adalah jumlah sampel. Hasil dari derajat kebebasan 1/degree of freedom $1(d f)=4-1=3$ dan derajat kebebasan $2 /$ degree of freedom $2(d f)=77-4=73$. 
Tabel 4.6

Hasil Uji F (Simultan)

\begin{tabular}{|c|c|c|c|c|c|}
\hline df1 & df2 & F $_{\text {tabel }}$ & F $_{\text {hitung }}$ & Sig & Keputusan \\
\hline 3 & 73 & 2,730 & 17,126 & 0,000 & Ho Ditolak \\
\hline
\end{tabular}

Sumber: data diolah SPSS 21.0 (2018)

Berdasarkan tabel 4.18, dapat diketahui nilai $\mathrm{F}_{\text {hitung }}>\mathrm{F}_{\text {tabel }}$ atau 17,126 $>2,730$ dan nilai signifikan $<$ $0,05(0,000<0,05)$, maka $\mathrm{Ho}_{4}$ ditolak dan $\mathrm{Ha}_{4}$ diterima yaitu bahwa variabel harga, kualitas produk, dan citra merek secara simultan berpengaruh terhadap variabel keputusan pembelian.

\section{Simpulan Dan Saran}

\subsection{Simpulan}

Berdasarkan perumusan masalah, hipotesis penelitian, dan pembahasan hasil penelitian yang telah sudah diuraikan pada bab-bab sebelumnya, maka penulis dapat memberikan simpulan sebagai berikut:

1. Variabel harga berpengaruh signifikan terhadap keputusan pembelian dengan hasil uji $t$ (parsial) didapat $\mathrm{t}_{\text {hitung }}>\mathrm{t}_{\text {tabel }}(3,693>1,993)$ dengan nilai signifikasinya didapat sebesar $0,000<0,05$, maka Ho ditolak dan Ha diterima.

2. Variabel kualitas produk berpengaruh signifikan terhadap keputusan pembelian dengan hasil uji $\mathrm{t}$ (parsial) didapat $\mathrm{t}_{\text {hitung }}>\mathrm{t}_{\text {tabel }}(2,787>1,993)$ dengan nilai signifikasinya didapat sebesar $0,007<$ 0,05 , maka Ho ditolak dan Ha diterima.

3. Variabel citra merek berpengaruh signifikan terhadap keputusan pembelian dengan hasil uji t (parsial) didapat $\mathrm{t}_{\text {hitung }}>\mathrm{t}_{\text {tabel }}(2,289>1,993)$ dengan nilai signifikasinya didapat sebesar $0,025<$ 0,05 , maka Ho ditolak dan Ha diterima.

4. Variabel harga, kualitas produk, dan citra merek secara simultan berpengaruh signifikan terhadap variabel keputusan pembelian dengan hasil uji $\mathrm{F}$ (simultan) didapat $\mathrm{F}_{\text {hitung }}>\mathrm{F}_{\text {tabel }}(17,126$ $>2,730$ ) dengan nilai signifikasinya didapat sebesar $0,000<0,05$, maka Ho ditolak dan Ha diterima. Besarnya koefisien determinasi sebesar 0,389 atau 38,9\% yang berarti variabelvariabel bebas yang terdiri dari harga, kualitas produk, dan citra merek dapat memberikan kontribusi sebesar 38,9\% terhadap keputusan pembelian, sedangkan sisanya sebesar $61,1 \%$ dipengaruhi oleh faktor-faktor lain yang tidak dibahas di dalam penelitian ini.

\subsection{Saran}

Berdasarkan simpulan di atas, maka penulis memberikan beberapa saran sebagai berikut:

1. Berdasarkan pembahasan yang penulis lakukan bahwa variabel harga lebih dominan dengan nilai $_{t_{\text {hitung }}}$ didapat sebesar 3,693 dengan nilai signifikasinya didapat sebesar 0,000 , oleh karena itu penulis menyarankan kepada calon konsumen untuk memilih kecap manis merek Bango.

2. Dalam penelitian ini, sebaiknya calon konsumen memilih kecap manis merek Bango karena harganya yang terjangkau, kualitas produk yang menarik, dan mudah diingat di benak calon konsumen.

3. Untuk penelitian selanjutnya, apabila meneliti permasalahan yang sama tentang keputusan pembelian disarankan agar menggunakan dan menambah variabel-variabel yang lain. 


\section{Daftar Pustaka}

Alma, Buchari. 2016. Manajemen Pemasaran dan Pemasaran Jasa. PenerbitAlfabeta. Bandung. Amirullah. 2015. Pengantar Manajemen. Penerbit Mitra Wacana Media. Bogor.

Arifin, Rois dan Muhammad, Helmi. 2016. Pengantar Manajemen. Penerbit Empatdua. Jawa Timur. Assauri, Sofjan. 2017. Manajemen Pemasaran. Penerbit Rajawali Pers. Jakarta.

Boneta, Gisda dan Hamzah, Ramadhani. 2014. Pengaruh Produk, Harga, Promosi Dan Saluran Distribusi Terhadap Keputusan Pembelian Air Minum Dalam Kemasan Merek Aqua. Jurnal Ekonomi Bisnis Indonesia, Vol 09 No. 02 Desember 2014 ISSN NO 0126-1991. Fakultas Ekonomi. Jurusan Manajemen. Sekolah Tinggi Ilmu Ekonomi Bisnis Indonesia. Jakarta. https://jurnal.stiebi.ac.id/index.php/Jebi

Ghozali, Imam. 2016. Aplikasi Analisis Multivariate Dengan Program IBM SPSS 23. Penerbit Badan Penerbit Universitas Diponegoro. Semarang.

Kotler, Philip dan Amstrong, Gary. 2012. Principles Of Marketing. Pearson Education Limited. New Jersey.

Priyatno, Duwi. 2013. Analisis Korelasi, Regresi dan Multivariate dengan SPSS. Penerbit Gava Media. Yogyakarta.

Sangadji, Etta Mamang dan Sopiah. 2013. Perilaku Konsumen. Penerbit Andi. Yogyakarta.

Sugiyono. 2016. Metode Penelitian Kuantitatif, Kualitatif dan R\&D. Penerbit Alfabeta. Bandung.

Sujarweni, V. Wiratna. 2015. Metodologi Penelitian Bisnis Dan Ekonomi. Penerbit Pustaka Baru Press. Yogyakarta.

.2018. Metodologi Penelitian Bisnis Dan Ekonomi Pendekatan Kuantitatif. Penerbit Pustaka Baru Press. Yogyakarta.

Sule, Ernie Tisnawati dan Saefullah, Kurniawan. 2017. Pengantar Manajemen. Penerbit Kencana. Jakarta.

Sunyoto, Danang. 2014. Dasar-Dasar Manajemen Pemasaran. Penerbit CAPS (Center of Academic Publishing Service). Yogyakarta.

Taniredja, Tukiran dan Mustafidah, Hidayati. 2014. Penelitian Kuantitatif (Sebuah Pengantar). Penerbit Alfabeta. Bandung.

Wulandari, Arviana. 2016. Pengaruh Harga, Promosi Dan Kualitas Terhadap Keputusan Pembelian Produk Alkohol One Med Di Jakarta. Jurnal Ekonomi Bisnis Indonesia, Vol 11 No. 01 Juni 2016 ISSN NO 0126-1991. Fakultas Ekonomi. Jurusan Manajemen. Sekolah Tinggi Ilmu Ekonomi Bisnis Indonesia. Jakarta. https://jurnal.stiebi.ac.id/index.php/Jebi.

Yulianingsih, Anna dan Sutarti. 2017. Analisis Pengaruh Promosi, Lokasi, Harga Dan Kualitas Pelayanan Terhadap Keputusan Pembelian Pada Roti Bakar 88 Tangerang. Jurnal Ekonomi Bisnis Indonesia, Vol 12 No. 01 Juni 2017 ISSN NO 0126-1991. Fakultas Ekonomi. Jurusan Manajemen. Sekolah Tinggi Ilmu Ekonomi Bisnis Indonesia. Jakarta. https://jurnal.stiebi.ac.id/index.php/Jebi. 